\title{
STUDI KEBIJAKAN PEMBANGUNAN PERTANIAN DALAM UPAYA PENINGKATAN PRODUKSI KOMODITAS UNGGULAN BERAS ADAN DAN BINAMUD DI DESA BINUANG KECAMATAN KRAYAN TENGAH KABUPATEN NUNUKAN
}

\author{
Drs. Said Zulkifli, M.Si. \\ Dosen Ilmu Administrasi Publik FISIP Universitas Widya Gama Mahakam Samarinda \\ e-mail: saidzulkifli@uwgm.ac.id \\ Rusli, S.E., M.Si. \\ Dosen Ilmu Administrasi Publik FISIP Universitas Widya Gama Mahakam Samarinda \\ e-mail: rusli@uwgm.ac.id \\ Daniel \\ Alumni Ilmu Administrasi Publik FISIP Universitas Widya Gama Mahakam Samarinda
}

\begin{abstract}
Abstrak
Pembangunan Pertanian merupakan kebijakan pemerintah, termasuk pembangunan pertanian yang bersifat kearifan lokal, dalam hal ini yakni komuditas unggulan Beras Adan dan Binamud di Desa Binuang Kecamatan Krayan Tengah Kabupaten Nunukan. Tujuan dalam penelitian ini yakni untuk mengatahui kebijakan dalam meningkatkan pendapatan petani melalui produksi komoditas unggulan Beras Adan dan Binamud serta untuk mengatahui faktor-faktor penghambat dan pendukung kebijakan dalam meningkatkan pendapatan petani melalui peningkatan produktifitas komoditas unggulan Beras Adan dan Binamud di Desa Binuang Kecamatan Krayan Tengah Kabupaten Nunukan. Penelitian bersifat deskriptif kualitatif, dengan 5 (lima) informan secara purposive Sampling. Untuk Analisa data menggunakan analisis data interaktif dari Matthew, B.Milles dan A.Huberman.

Hasil Penelitian menunjukan bahwa Bahwa Kebijakan Pembangunan Pertanian, telah dilakukan dikabupaten Nunukan melalui Peraturan Bupati tentang Rencana Pembangunan jangka menengah daerah (RPJMD) 2015-2019 Pembangunan Pertanian, bahwa Upaya Peningkatan Produksi Komoditas Unggulan Beras Adan dan Binamud di Desa Binuang Kecamatan Krayan Tengah tidak lepas dari Kebijakan Pemerintah Kabupaten Nunukan dan upaya menempatkan Kecamatan Karayan Tengah, khususnya Desa Binuang sebagai Lumbung Padi Adan dan Binamud dan bahwa Produksi Komoditas Unggulan Beras Adan dan Binamud yang memiliki nilai Ekonomi Tinggi atau nilai jual yang cukup tinggi yang saat ini telah dilakukan melalui intersitikasi Beras Adan dan Binamud dalam upaya meningkatkan Pendapatan Masyarakat Desa Binuang. Faktor pendukung yakni harga yang cukup tinggi, sedangkan faktor penghambat adalah jarak yang cukup jauh untuk menjual ke daerah lain.
\end{abstract}

Kata Kunci: Kebijakan Pembangunan Pertanian, Beras Adan, Binamud, Desa Binuang Kecamatan Krayan Tengah Kabupaten Nunukan

\begin{abstract}
Agricultural Development is a government policy, including agricultural development that is local wisdom, in this case the superior commodity Rice Adan and Binamud in Binuang Village, Krayan Tengah District, Kabupaten Nunukan. The purpose of this research is to know the policy in increasing the income of farmers through the production of superior commodities Rice Adan and Binamud as well as to know the factors of inhibiting and supporting policy in increasing the income of farmers through increased productivity of superior commodities Rice Adan and Binamud in Binuang
\end{abstract}


Village District Krayan Tengah District, Kabupaten Nunukan. The research is descriptive qualitative, with 5 (five) informants by purposive sampling. For data analysis use interactive data analysis from Matthew, B.Milles and A.Huberman.

The result of the research shows that the Agricultural Development Policy has been done in Kabupaten Nunukan through the Regent Regulation on Regional Medium-Term Development Plan (RPJMD) 2015-2019 Agricultural Development, that Efforts to Increase Production of Rice Commodity Adan and Binamud in Binuang Village, Krayan Tengah Sub-district can not be separated from The policy of the Nunukan District Government and the efforts to locate Kecamatan Karayan Tengah, especially Binuang Village as center of Padi Adan and Binamud and that Production of Rice Commodities of Adan and Binamud Rice that have high economic value or high selling value which currently has been done through Rice Adan and Binamud in an effort to increase the income of Binuang Village Society. Supporting factor that is high enough price, while the inhibiting factor is a long distance to sell to other areas.

Keywords: Agricultural Development Policy, Adan Rice, Binamud, Binuang Village, Krayan Tengah District, Kabupaten Nunukan

\section{Pendahuluan}

Indonesia merupakan Negara agraris yang memiliki potensi besar dan sumber daya alam yang melimpah untuk produk pertanian. Di sektor pertanian Indonesia memiliki beragam jenis tenaman, hal ini didukung kondisi iklim tropis yang berbeda.

Pertanian merupakan sektor primer yang mendominasi aktivitas Perekonomian, terutama di Kabupaten Nunukan, Provinsi Kalimantan Utara. Kabupaten ini memiliki beberapa komoditas untuk tanaman padi dan palawija yaitu padi sawah, padi ladang, jagung kedelai, kacang tanah, kacang hijau, ubi kayu dan ubi jalar. Luas lahan pertanian padi dan Palawija Tahun 2014 masih didominasi oleh lahan pertanian padi sawah seluas 8.486 hektar dan padi ladang seluas 2.181 hektar. Pada tahun 2014 luas panen padi sawah dan ladang di Kabupaten Nunukan mengalami kenaikan sebesar 9,42\% dari komoditas pertanian lain nya (data BPS Kabupaten Nunukan 2014).

Berdasarkan Data BPS (badan pusat statistik) Kabupaten Nunukan 2014, jumlah kecamatan yang berada di daerah Kabupaten Nunukan adalah 13 Kecamatan yaitu Kecamatan Lumbis, Kecamatan Lumbis Ogong, Kecamatan Sebatik Tengah, Kecamatan Sebatik Barat, Kecamatan Sebatik Timur, Kecamatan Sebatik Utara, Kecamatan Sebuku, Kecamatan Krayan, Kecamatan Krayan Selatan, Kecamatan Sei Menggaris, Kecamatan Sembakung, Kecamatan Tulin Onsoi, dan Kecamatan Sembakung Atulai.

Namun pada tahun 2016 melalui Peraturan Daerah Kabupaten Nunukan Nomor 11 Tahun 2015, Kecamatan Krayan Tengah telah dimekarkan dari kecamatan sebelumnya yaitu kecamatan Krayan Selatan, dengan cakup wilayah kecamatan Krayan Tengah adalah Desa Tang Payeh, Desa Long Rungan, Desa Long Kelupan, Desa Long Padi, Desa 
Tang Badui, Desa Binuang, Desa Long Mutan, Desa Pa'Milau, Desa Ba'Liku, Desa Long Rian dan Desa Pa'Yalau.

Beras Adan merupakan beras terbaik di antara varietas beras lokal yang ditanam oleh masyarakat Desa Binuang, oleh sebab itu hingga saat ini Beras Adan masih dibudidayakan secara tradisional di Desa Binuang dan daerah Krayan secara umum dengan umur panen beras adan ini mencapai 5-6 bulan. Beras ini terkenal dengan bijibijian kecil dan tekstu halus serta rasa yang pulen dan khas.

Pada umumnya Beras ini ada 3 jenis yaitu Beras Adan Putih, Beras Adan Merah dan Beras Adan Hitam. Sedangkan Binamut merupakan tanama sejenis padi yang ditanam sekitar 1 bulan atau 20 hari lebih awal dari penanaman padi, bentuk dari binamut ini sangat kecil seukurang biji sawi (kurang lebih sama) dan berwarna kuning, jika dilihat sekilas binamut seperti telur ikan mas.

Berdasarkan Data Desa Binuang, 2016, hasil panen Beras Adan pertahun 1,480 karung sampai dengan 4.900 karung ( isi satu karung $15 \mathrm{~kg}$ ) dan hasil panen Binamud pertahun mencapai 300 gantang sampain 600 gantang (gantang merupakan satuan yang biasa digunakan masyarakat dalam menjual binamut, satu gantang sama dengan 3,5 kg). Dengan harga jual Beras Adan mencapai Rp. 280.000,00 sampai dengan Rp. 300.000,00. sedangkan harga jual Binamud mencapai Rp. 150.000,00 sampai dengan Rp. 200.000,00. Biasanya beras Adan dan Binamut ini diperjual belikan secara teradisonal kenegara tetangga seperti Malaysia dan Berunai Darrusalem serta di akui oleh masyarakat yang berada di Malaysia dan Brunai Darussalam.

Berdasarkan Peraturan Mentri Pertanian Republik Indonesia Nomor 14/Permentan/OT.140/3/2015 Tentang Pedoman Pengawalan dan Pendamping Terpadu Penyuluhan, Mahasiswa, dan Bintara Pembina Desa dalam Rangka Upayah Khusus Peningkatan Produktifitas Padi, Jagung, dan Kedelai. Maka Peranan Pemerintah Desa sangat lah penting kerena seperti yang di katahui bahwa pertumbuhan pembangunan Desa tidak akan lepas dari sektor pertanian, mengingat potensi sumber daya alam yang dapat dikelola cukup melimpah serta daya dukung sumber daya manusia yang ada di perdesaan (petani lokal) cukup tersedia. Sehingga apabila hal tersebut dikelola dengan baik dan terencana, serta memacu pada pembangunan dan pengembangan potensi yang ada, maka pembangunan ditingkat perdesaan akan semakin berkembang.

Hal ini sejalan dengan arah dan kebijakan pembangunan pertanian yang telah dicanangkan pemerintah, yaitu terwujudnya ketahanan pangan diwilayah/daerahnya masing-masing serta mendorong dan mengembangkan produksi komoditas unggulan yang dimilikinya. 
Namun yang terjadi dilapangan selama pengamatan peneliti, Kebijakan Pembangunan Pertanian belum terlaksana sehingga belum mampu meningkatkan pendapatan atau taraf hidup masyarakat yang ada di Desa Binuang melalui komoditas unggulan yang ada di Desa Binuang yaitu beras Adan dan Binamut, padahal beras Adan dan Binamut ini memiliki harga jual yang cukup tinggi dari produksi hasil pertanian lainnya.

\subsection{Permasalahan}

Adapun yang menjadi permasalahan dalam penelitian ini yakni bagaimanakah kebijakan dalam upaya petani melalui peningkatan produktifitas komoditas unggulan Beras Adan dan Binamud?, serta Apakah terdapat faktor-faktor yang mendukung dan menghambat dalam meningkatkan pendapatan petani Desa Binuang Kecamatan Krayan Tengah Kabupaten Nunukan?

\subsection{Tujuan}

Adapun yang menjadi tujuan dalam penelitian ini yakni untuk mengatahui kebijakan dalam meningkatkan pendapatan petani melalui produksi komoditas unggulan Beras Adan dan Binamud di Desa Binuang Kecamatan Krayan Tengah, serta untuk mengatahui faktor-faktor penghambat dan pendukung kebijakan dalam meningkatkan pendapatan petani melalui peningkatan produktifitas komoditas unggulan Beras Adan dan Binamud di Desa Binuang Kecamatan Krayan Tengah Kabupaten Nunukan.

\section{Kerangka Teori}

\subsection{Pembangunan Pertanian}

Pembangunan Pertanian adalah suatu proses yang ditujukan untuk selalu menambah produksi pertanian untuk menambah produksi pertanian untuk tiap-tiap konsumen, yang sekaligus mempertinggi pendapatan dan produktivitas usaha tiap-tiap petani.

Menurut A.T. Mosher (1987:68) "bahwa pembangunan pertanian adalah suatu bagian integral daripada pembangunan ekonomi dan masyarakat secara umum". Selanjutnya A.T. Mosher (1987:69) mengatakan "Secara luas pembangunan pertanian bukan hanya proses atau kegiatan menambah produksi pertanian melainkan sebuah proses yang menghasilkan perubahan sosial baik nilai, norma, perilaku, lembaga, sosial dan sebagainya demi mencapai pertumbuhan ekonomi dan meningkatkan kesejahteraan petani dan masyarakat yang lebih baik". A.T. Mosher (1987:70) mengatakan ada 5 butir syarat mutlak pembangunan pertanian yaitu:
a. Pemasaran untuk hasil-hasil produksi usaha tani
b. Teknologi yang selalu berubah
c. Sarana produksi dan alat-alat mesin pertanian
d. Perangsang bagi petani untuk meningkatkanproduksi
e. Transportasi / pengangkutan. 
Menurut Soedarsono Hadisapoetro ( 1975:17) "mengungkapkan bahwa Pembangunan Pertanian adalah suatu proses yang ditujukan untuk selalu menambah produksi pertanian untuk menambah produksi pertanian untuk tiap-tiap konsumen, yang sekaligus mempertinggi pendapatan dan produktivitas usaha tiap-tiap petani dengan jalan menambah modal dan skill untuk memperbesar turut campur tangannya manusia di dalam perkembangan tumbuh-tumbuhan dan hewan".

Berdasarkan penjelasan diatas maka peneli menarik kesimpulan bahwa pembanguan pertanian adalah proses yang ditujukan untuk selalu menambah produksi pertanian dan sekaligus mempertinggi pendapatan dan produktivitas usaha tiap-tiap petani.

\subsection{Produksi}

Menurut Sugiarto (2007:94), "Produksi adalah suatu kegiatan yang mengubah input menjadi output. Kegiatan tersebut dalam ekonomi biasa dinyatakan dalam fungsi produksi". Selanjutnya V.Gaspesz (2004:30) mengatakan"Produksi merupakan fungsi pokok dalam setiap organisasi yang mencakup aktivitas yang bertanggung jawab untuk menciptakan nilai tambah produk yang merupakan output dari setiap organisasi industri itu".

Menurut Sofjan Assauri (2008:17) mengatakan “ yang dimaksud dengan produksi adalah kegiatan yang mentranformasikan masukan (output), mencakup semua aktivitas atau kegiatan yang menghasilkan barang atau jasa, seta kegiatan-kegiatan lain yang mendukung atau menunjang usaha untuk menghasilkan produk tersebut yang berupa baran-barang atau jasa".

Menurut I. Fahmi (2012:2) "Produksi adalah suatu yang dihasilkan oleh perusahan baik bentuk barang maupun jasa dalam suatu preode waktu selanjutnya dihitung sebagi nilai tambahan bagi prusahaan. Selanjutnya Irham Fahmi (2012:3) mengatakan produksi dapat ditinjau dari dua sudut yaitu Produksi dalam arti sempit dan Produksi dalam arti luas:

a. Pengertian Produksi dalam arti sempit, yaitu mengubah bentuk barang menjadi barang baru.

b. Pengertian Produksi dalam arti sempit, yaitu usah yang menimbulkan kegunaan.

Selanjutnya Menurut I. Fahmi (2014:45). Juga menjelaskan "Bagian produksi dalam suatu organisasi bisnis memegang peran penting dalam usaha mempengaruhi suatu organisasi. Bagian produksi sering dilihat sebagai salah satu fungsi manajemen yang menentukan penciptaan produk serta turut mempengaruhi peningkatan dan penurunan penjualan. Artinya produk yang diproduksi harus selalu mengikuti standart pasar yang diinginkan, bukan diproduksi atas dasar mengejar target semata. Karena dengan kontinuitas yang stabil diharapkan mampu mewujudkan perolehan keuntungan yang stabil".

Berdasarkan pendapat ahli diatas maka peneliti menyimpulkan bahwa Produksi merupakan suatu kegiatan organisasi/perusahan yang dapat menghasilkan barang atau jasa, yang diawali dari pembelian bahan baku sampai pada hasil akhir yang baik kerena adanya proses. 


\subsection{Komoditas Unggulan}

Komoditas unggulan adalah sesuatu benda nyata yang relatif mudah diperdagangkan, dapat diserahkan secara fisik, dapat disimpan untuk suatu jangka waktu tertentu dan dapat dipertukarkan dengan produk lainnya dengan jenis yang sama, yang biasanya dapat dibeli atau dijual.

Menurut T. Tambunan (2010:18) "Komoditas unggulan adalah komoditi potensial yang dipandang dapat dipersaingkan dengan produk sejenis di daerah lain, karena disamping memiliki keunggulan komparatif juga memiliki efesiensi usaha yang tinggi”.

Menurut Saragih (2010:14), Mengatakan "komoditas unggulan agribisnis diartikan sebagai komoditas basis agribisnis yang dihasilkan secara berlebihan dalam pengertian lebih untuk dipergunakan oleh masyarakat dalam suatu wilayah tertentu, sehingga kelebihan tersebut dapat dijual ke luar wilayah tersebut".

Menurut Prihawantoro,(2002:18-20) "komoditas unggulan dapat memberikan kontribusi yang signifikan pada peningkatan produksi, pendapatan, maupun pengeluaran". Selanjutnya Meiningsih, (2010:8) mengatakan "Komoditas dikatakan unggulan apabila memiliki kontribusi yang besar minimal untuk produsen itu sendri berdasarkan criteria tertentu".

Oleh sebab itu penelitih menyimpulkan bahwa komoniti unggulan adalah merupakan komoditas andalan yang memiliki posisi strategis untuk di kembangkan disuatu wilayah yang dapat memberikan kontribusi yang signifikan pada peningkatan produksi, pendapatan, maupun pengeluaran.

\subsection{Alur Pikir}

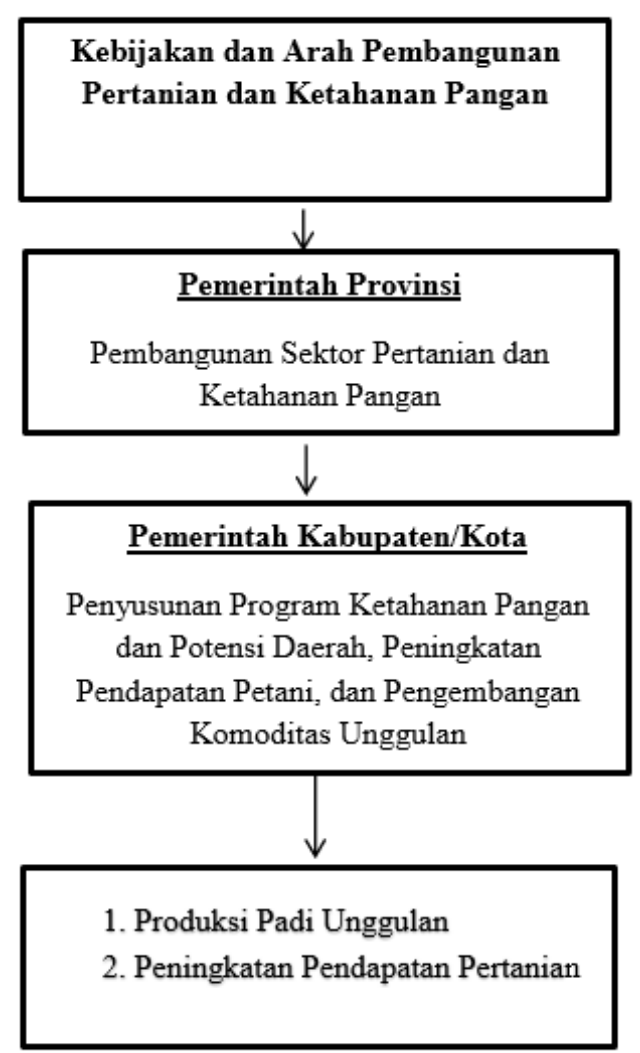




\section{Metode}

Penelitian yang digunakan dalam penelitian ini adalah penelitian deskriptif kualitatif. Pemilihan 5 (lima) informan dengan metode purposive Sampling. Untuk Analisa data menggunakan analisis data interaktif dari Matthew, B.Milles dan A.Huberman (1992:19) yang meliputi empat komponen yaitu; Pengumpulan Data Reduksi Data Penyajian Data, dan Pengambilan Kesimpulan.

\section{Hasil}

\subsection{Gambaran Umum Lokasi Penelitian}

Penduduk Desa Binuang Kecamatan Krayan Tengah secara umum mayoritas asli Suku Dayak Lengilo dan Lundayeh dengan jumlah penduduk secara keseluruhan 389 jiwa. Jumlah Laki-laki sebanyak 178 jiwa dan jumlah Perempuan sebanyak 211 jiwa. Dari 389 jiwa penduduk Desa Binuang, 250 jiwa diantaranya merupakan keluarga kurang mampu (miskin) dengan mayoritas pekerjaan masyarakat yang ada di Desa Binuang sebagai Pertani atau Bercocok tanam.

Tingkat pendidikan masyarat Desa Binuang masih sangat rendah, tidak berbanding seimbang dengan jumlah pendidik sumber daya manusianya, ini merupakan permasalahan utama penyebab munculnya permasalahan diberbagai aspek.

4.2. Kebijakan Dalam Peningkatan Petani Melalui Peningkatan Produksi Komoditas Unggulan Beras Adan dan Binamud di Desa Binuang Kecamatan Krayan Tengah

Kebijakan pembangunan pertanian ini suda di jelaskan dalam RPJMND 2015-2019 ada pun sasaran utama dalam kebijakan ini adalah 2015-2019 dalam Pembangunan Pertanian; Meningkatkan Kapasitas Produksi Melalui Peningkatan Produktivitas dan Perluasan Areal Pertanian, Meningkatkan Daya Saing dan Nilai Tambah Komoditas Pertanian, Meningkatkan Produksi dan Diverfikasi Sumber Daya Pertanian, Mengelolah dan Pemenfaatan Keanekaragaman Hayati dan Memperkuat Kapasitas Mitigasi dan Adaptasi Perubahan Iklim.

Selanjutnya Peraturan Daerah Kabupaten Nunukan Nomor 18 Tahun 2006 Tentang Kewenangan Desa, pada Bab IV Kewenangan Desa Berupa Urusan Pemerintah Yang Menjadi Kewenangan Pemerintah Kabupaten Yang Di Serahkan Pengaturannya Kepada DESA Bagian Pertama Jenis Urusan Pemerintahan, Jenis Urusan Pemerintahan Pasal 5 (1) Urusan Pemerintahan Kabupaten yang dapat diserahkan pengaturannya kepada Desa antara lain: Bidang Pertanian dan Ketahanan Pangan, Bidang Pertambangan dan Energi serta Sumber Daya Mineral, Bidang Kehutanan dan Perkebunan, Bidang Perindustrian dan Perdagangan, Bidang Koperasi dan Usaha Kecil dan Menengah, Bidang Penanaman Modal, Bidang Tenaga Kerja dan Transmigrasi, Bidang Kesehatan, Bidang Pendidikan dan Kebudayaan.

Dari hasil Penelitian Pemerintah Desa Membuat Peraturan Desa dalam Upaya Peningkatan Produksi Komoditas Unggulan Beras Adan dan Binamud bertujuan untuk meningkatan Pendapatan Petani Desa Binuang dalam jangka waktu yang panjang, melalui Peningkatan Produksi hasil panen Beras Adan dan Binamud, hal ini mengaju pada mayoritas perkerjaan masyarat yang ada di Desa Binuang sebagai Petani dan luas lahan 
Pertanian yang cukup, namun belum bisa dimanfaatkan secara optimal sehingga menjadi permasalahan utama dalam Upaya Peningkatan Pendapatan Petani Desa Binuang.

\subsubsection{Meningkatkan Pendapatan Petani}

Pendapatan Masyarakat Desa Binuang belum optimal sedangkan di Desa Binuang memiliki potensi pertanian unggulan/andalan ekspor dan mempunyai nilai jual yang cukup tinggi.

Kendala dalam Mengekspor hasil peranian Desa Binuang ini adalah jalan dara yang kurang mendukung, serta selain itu permasalahan dalam meningkatkan pendapatan masyarat Desa Binuang ialah keadan atau posisi Desa Binuang yang jauh dari ibu Kota Kabupaten Nunukan. akses satu-satunya melalui pesawat dikernakan akses darat belum ada, ada pun hasil panen beras adan dan binamud ini sering di pasarkan ke negara tetangga Malaysia, biar pun Beras Adan dan Binamud di perjual belikan ke Negara tetangga Malaysia masih banyak bayak masalah yang dihadapi seperti penjualan yang dilakukan secara tradisional dan juga kondisi jalan yang kurang memdukung jalan dari Desa Binuang ke daerah perbatasan Ba'Kelalan (malaysia) tergantung dengan cuaca, jika cuaca hujan jalan dara tidak bisa digunakan atau dilewati dengan kendaraan roda dua maupun roda empat.

\subsubsection{Meningkatkan Produksi Komoditas Unggulan Ekspor Beras Adan dan Binamud}

Pendapatan Masyaraka Desa Binuang belum optimal sedangkan di Desa Binuang memiliki potensi pertanian unggulan/andalan ekspor dan mempunyai nilai jual yang cukup tinggi.

Kendala dalam Mengekspor hasil peranian Desa Binuang ini adalah jalan dara yang kurang mendukung, serta selain itu permasalahan dalam meningkatkan pendapatan masyarat Desa Binuang ialah keadan atau posisi Desa Binuang yang jauh dari ibu Kota Kabupaten Nunukan. akses satu-satunya melalui pesawat dikernakan akses darat belum ada, ada pun hasil panen beras adan dan binamud ini sering di pasarkan ke negara tetangga Malaysia, biar pun Beras Adan dan Binamud di perjual belikan ke Negara tetangga Malaysia masih banyak bayak masalah yang dihadapi seperti penjualan yang dilakukan secara tradisional dan juga kondisi jalan yang kurang memdukung jalan dari Desa Binuang ke daerah perbatasan Ba'Kelalan (malaysia) tergantung dengan cuaca, jika cuaca hujan jalan dara tidak bisa digunakan atau dilewati dengan kendaraan roda dua maupun roda empat.

\subsubsection{Meningkatkan Pendapatan Petani Desa Binuang Melalui Upaya Peningkatan Produksi Komoditas Beras Adan dan Binamud}

Dalam meningkatkan Pendapatan, Masyarat Desa Binuang sudah melakukan beberapa hal seperti perluasan lahan dan penanaman bibit Padi Adan dan Binamud dalam jumlah yang banyak seperti yang telah di atur dalam PERDES guna meningkatkan hasil Produksi atau hasil Panen setiap tahunnya, karena mayoritas pekerjaan masyarat yang ada di Desa Binuang ini adalah Petani oleh sebab itu petani wajib tiap tahun meningkatkan hasil Panen Komoditas Unggulan Beras Adan dan Binamud ini guna Mengingkatkan penghasilan masyarat itu sendiri.

4.3. Faktor Yang Mendukung dan Menghambat Dalam Upaya Meningkatkan Pendapatan Petani Desa Binuang Kecamatan Krayan Tengah Kabupaten Nunukan 


\subsubsection{Faktor Pendukung}

Faktor pendukung dalam peningkatan pendapatan masyarat desa binuang ini adanya luas wilayah produktif yang dijadikan lahan sawah dan ladang cukup luas dan keberadaan Desa Binuang ini di daerah perbatasan Malaysia sehingga dalam mejual hasil pertanian unggulan yang ada, serta pendukung lainnya sumber daya manusia yang ada didesa ini sebagian besar berprofesi sebagai petani atau bercocok tanam.

\subsubsection{Faktor Penghambat}

Faktor penghambat dalam Peningkatan Pendapatan Masyarat Desa Binuang adalah Petani belum memiliki pasar untuk penjualan hasil Pertanian serta akses jalan yang kurang baik dan hanya bisa digunakan pada saat kemarau, faktor penghambat lainnya adalah harga Bahan Bakar Minyak (BBM) yang cukup mahal dan jumlah gilingan Padi yang sedikit

\section{Simpulan}

1) Kebijakan Pembangunan Pertanian, telah dilakukan /dilaksanakan dikabupaten Nunukan, Khususnya di Desa Binuang Kecamatan Krayan Tengah, Sebagaimana ditulis dalam Praturan/Ketentuan Peraturan Bupati daan seperti di jelaskan dalam Rencana Pembangunan jangka menengah Nasional (RPJMN) 2015-2019 Pembangunan Pertanian

2) Upaya Peningkatan Produksi Komoditas Unggulan Beras Adan dan Binamud di Desa Binuang Kecamatan Krayan Tengah tidak lepas dari Kebijakan Pemerintah Kabupaten Nunukan dan upaya menempatkan Kecamatan Karayan Tengah, khususnya Desa Binuang sebagai Lumbung Padi Adan dan Binamud. Produksi

3) Komoditas Unggulan Beras Adan dan Binamud yang memiliki nilai Ekonomi Tinggi atau nilai jual yang cukup tinggi yang saat ini telah dilakukan melalui intersitikasi Beras Adan dan Binamud dan Upaya Meningkatkan Pendapatan Masyarakat Desa Binuang.

4) Faktor pendukung dalam peningkatan pendapatan masyarakat petani Desa Binuang adalah harga Beras Adan dan Binamud yang menjadi Unggulan Desa cukup mahal, posisi Desa Binuang dekat dengan Negara Tetangga Malaysia dan dapat dijangkau dengang akses jalan darat menggunakan roda dua dan empat. Faktor prndukung lainnya luas lahan produktif yang dijadikan sawah dan ladang cukup luas sehingga dapat di manfaatkan dalam meningkatkan Produksi Beras Adan dan Binamud.

5) Faktor Penghambat dalam Peningkatan Pendapatan Masyarakat Petani Desa Binuang adalah jauhnya jarak Desa Binuang dengan Ibu Kota Kabupaten Nunukan dan Daerah-daerah lainya yang berada Kalimantan Utara hanya dapat dilalui atau dijangkau dengan menggunakan akses Udara atau menggunakan Pesawat Terbang. Penghambat lainnya adalah kondisi jalan menuju Negara Tetangga Malaysia hanya bisa dilewati pada saat musim kemarau, jika musim hujan jalan darat menuju Negara Tetangga Malaysia tidak bisa dilewatin kendaran roda dua dan roda empat dan jumlah penggilingan Padi di Desa Binuang juga sangat kurang

\section{Daftar Pustaka}

ARI SETIAWAN, 2012. Penelitian dan Evaluasi Pendidikan, Universitas Sarjanawiyata Tamansiswa Yogyakarta

ANDI PRASTOWO, 2012. Metode penelitian kualitatif. Penerbit Ar-ruzz Media, Yogyakarta. 
A.T. MOSHER, 1987. Menggerakkan dan Membangun .Pertanian Jayaguna, , Jakarta.

B. PRASETYON dan L.M JANNAH, 2005. Metode Penelitian Kualitatif. Penerbit Raja Gafindo, Jakarta

B. SARAGIH. 2010. Agribisnis Paradigma Baru Pembangunan Ekonomi Berbasis Pertanian. Penerbit IPB Press. Bogor

BURHAN BUNGIN. 2012. Analisis Data Penelitian Kualitatif. Penerbit Raja Grafindo Persada. Jakarta

B. PRASTYO \& LINA MIFTAHUL JANNAH ,2005. Metod Penelitian Kuantitatif Teori \& Aplikasinya. Penerbit. PT Raja Grafindo Persada.jakarta

CHOLID NARBUKO dan ABU ACHMADI, 2001, Metode Penelitian. Penerbit Bumi Aksara, Jakarta

IRHAM FAMI,2012. Manajemen Produksi dan Operasi. Alfabeta.Bandung.

2014. Manajemen Produksi dan Operasi. Alfabeta.Bandung.

LEXY J.MOLEONG, 2000. Metode Penelitian Kualitatif. Penerbit Remaja Rosdakarya.

2002. Metode Penelitian Kualitatif. Penerbit Remaja Rosdakarya.

2004.Metode Penelitian Kualitatif. Penerbit Remaja Rosdakarya.

2009. Metode Penelitian Kualitatif. Penerbit Remaja Rosdakarya.

MEININGSIH, 2010. Technology Balance of Payment: Pengukuran Neraca Perdagangan Teknologi Indonesia. Penerbit UPT BMR LIPI Press. Jakarta

MISBAHUDDI DAN IQBAL HASAN, 2013. POKOK-POKOK MATERI STATISTIK 1 (STATISTIK DESKRIPTIF) .Penerbit Bumi Aksara. Jakarta

MUHAMMAD IDRUS, 2009. Metode Penelitian Ilmu Sosial. Penerbit Erlangga. Yogyakarta

NASUTION. 2003. Metode Research, PT. Bumi Aksara. Jakarta

NYOMAN KUTHA RATNA, 2010. Metodologi Penelitian: Kajian Budaya dan Ilmu. Sosial Humaniora Pada Umumnya. Pustaka Pelajar Yogyakarta

RIANTO ADI, 2010. Metodologi Penelitian Sosial dan Hukum, Penerbit Yayasan Obor Indonesia, Jakarta.

PRIHAWANTORO, 2002. Pengembangan wilayah dan otonomi daerah. Penerbit pusat kebijakan teknologi dan pengembangan wilayah. Jakarta

SYOFIAN SIREGAR, 2014. Metode Penelitian Kuantitatif SPSS. Penerbit Prenada Media Grup. Jakarta.

SIMAMORA, 2004. Manajemen sumber daya manusia /. Edisi, : Ed. 3, Cet ke 1. Penerbitan Bagian Penerbitan STIE YPKN. Yogyakarta

SUHARSIMI ARIKUNTO, 2013. Proses Penelelitian: Suatu Peraktek Pendekatan . Penerbit Rinika Cipta. Jakarta

SOFIAN ASSAURI, 2008. Manajemen Produksi dan Operasi. Penerbit Fakultas Ekonomi Universitas Indonesia. Jakarta.

SOEDARSONO HADISAPOETRO, 1975. Pembangunan Pertanian. Departemen Ekonomi Pertanian. Fakultas Pertanian. UGM.

SUGIARTO DKK, 2007. Ekonomi Mikro. Penerbit Gramedia Pustaka. Jakarta 
SUBAGYO, 2004. Statistik Induktif, Edisi 4, BPFE, Yogyakarta.

SOEDJADI, 2000. Kiat Pendidikan Matamatika di Indonesia: Konstatasi Keadaan Masa Kini Menuju Harapan Masa Depan. Penerbit Dirjen Pendidikan Tinggi.

SUKARDI, 2006. Metode Penelitian Pendidikan. Penerbit PT. Bumi Askara, Yogyakarta.

SUGIYONO, 2001. Metode penelitian kualitatif dan kuantitatif R\&D. Penerbit Alfabeta, Bandung

2008. Metode penelitian kualitatif dan kuantitatif R\&D. Penerbit Alfabeta, Bandung.

2009. Metode Penelitian Kuantitatif, Kualitatifdan R\&D. Alfabeta, Bandung

2010. Metode Penelitian Kuantitatif, Kualitatifdan R\&D. Alfabeta, Bandung

2012. Metode Penelitian Kuantitatif, Kualitatifdan R\&D. Alfabeta, Bandung

,2015. Metode penelitian kualitatif dan kuantitatif R\&D. Penerbit Alfabeta, Bandung.

T.TAMBUNAN, 2010. Pembangunan Pertanian Dan Ketahanan Pangan. Penerbit UI Press. Jakarta

ULBER SILALAHI, 2012. Metodologi. Penelitian. Penerbit Graha Ilmu. Bandung

VINCENT GASPERSZ, 2004. Production Planning And Inventory Control (Perencanaan Produksi dan Pengendalian Persedia) Penerbit Bumi Aksara. Jakarta

WINARNO SURACHMAD, 2006. Dasar- Dasar Teknik Research. Penerbit Transito. Bandung.

WIRATNA SUJARWENI, 2014. SPSS Untuk Penelitian. Pustaka Baru Press, Yogyakarta.

ZAINUDDIN.M, 2011. Metodologi Penelitian: Pendekatan Praktis dan Aplikasi. Penerbit Refika Aditama. Bandung 